\title{
PENGARUH ART THERAPY TERHADAP PREGNANCY-SPECIFIC DISTRESS PADA PEREMPUAN DEWASA AWAL YANG MENGALAMI KEHAMILAN PERTAMA
}

\author{
Anastasia Nadya Caestara, Monty P. Satiadarma, dan Widya Risnawaty \\ ${ }^{1}$ Program Studi Magister Psikologi, Universitas Tarumanagara \\ Email: anastasia.nadya16@gmail.com \\ ${ }^{2}$ Program Studi Magister Psikologi, Universitas Tarumanagara \\ Email: montys@fpsi.untar.ac.id \\ ${ }^{3}$ Program Studi Sarjana Psikologi, Universitas Tarumanagara \\ Email: widyar@fpsi.untar.ac.id
}

\begin{abstract}
ABSTRAK
Pregnancy-specific distress (PSD) yang merupakan perasaan khawatir atau terganggu terkait gejala fisik, perubahan bentuk tubuh, perubahan hubungan interpersonal dengan orang lain, proses persalinan, kesehatan bayi, cara merawat bayi, dan risiko dari perawatan medis yang dilakukan pada masa kehamilan. PSD dapat diatasi dengan art therapy dalam bentuk menggambar dan melukis agar partisipan dapat mengekspresikan perasaan negatif yang menyebabkan PSD. Tujuan penelitian ini adalah membuktikan apakah art therapy dengan menggambar dan melukis berpengaruh dalam menurunkan PSD. Karakteristik partisipan penelitian adalah perempuan dewasa awal yang sedang hamil pertama kali, memiliki usia kehamilan trimester pertama, dan mengalami PSD yang diukur dengan alat ukur Revised Prenatal Distress Questionnaire (NuPDQ). Penelitian ini menggunakan pendekatan mix method dengan desain onegroup pretest posttest design. Teknik sampling yang digunakan adalah purposive sampling. Jumlah sampel pada penelitian ini adalah 6 orang partisipan. Hasil penelitian menunjukkan art therapy efektif untuk menurunkan PSD pada seluruh partisipan. Art therapy dapat membantu partisipan mengekspresikan emosi dengan menggambar dan melukis.
\end{abstract}

Kata kunci: Art therapy, Kehamilan, Stres, Pregnancy-Specific Distress

\begin{abstract}
Pregnancy-specific distress (PSD) is a feeling of worry or disturbance related to physical symptoms, changes in body shape, changes in interpersonal relationships with others, labor, baby's health, how to care for babies, and the risk of medical care during pregnancy. PSD can be overcome with art therapy in the form of drawing and painting so that participants can express negative feelings that cause PSD. The purpose of this study is to prove whether art therapy by drawing and painting has an effect in reducing PSD. Characteristics of study participants were early adult women who were expecting for the first time, had gone through first trimester gestational age, and experienced PSD as measured by the Revised Prenatal Distress Questionnaire (NuPDQ). This research utilized mix method approach with one-group pretest posttest design. The sampling technique used was purposive sampling. The number of samples in this study were 6 participants. The result showed that art therapy was effective in reducing PSD in all participants. Art therapy can help participants express emotions by drawing and painting.
\end{abstract}

Keywords: Art therapy, Pregnancy, Stress, Pregnancy-Specific Distress

\section{PENDAHULUAN}

Kehamilan merupakan pengalaman penting untuk perempuan karena sedang mengandung janin yang akan menjadi generasi penerus keluarga. Pengalaman kehamilan hingga persalinan biasanya menjadi kenangan yang berarti pada perempuan hamil (Susanti, 2008). Kehadiran anak biasanya sangat diinginkan dalam perkawinan karena dianggap mampu meningkatkan kualitas dalam sebuah keluarga dan menyempurnakan hubungan perkawinan (Lestari, 2012). 
Jumlah ibu hamil di Indonesia pada tahun 2016 adalah 5.354.594. Estimasi jumlah kelahiran bayi yang hidup adalah 4.867 .813 dan kematian bayi adalah 486.781 . Jumlah ibu hamil yang banyak per tahun dan angka kematian bayi membuat ibu hamil menjadi perhatian pemerintah. Kementrian Kesehatan membuat program Indonesia Sehat tahun 2015-2019 yang ditetapkan melalui Keputusan Menteri Kesehatan R.I. Nomor HK.02.02/Menkes/ 52/2015. Sasaran dari Program Indonesia Sehat adalah meningkatnya derajat kesehatan dan status gizi masyarakat melalui upaya kesehatan dan pemberdayaan masyarakat yang didukung dengan perlindungan finansial dan pemerataan pelayanan kesehatan. Salah satu tujuannya adalah meningkatkan status kesehatan dan gizi ibu dan anak. Program ini juga termasuk meningkatkan kualitas kesehatan ibu hamil agar bayi yang dilahirkan sehat sehingga mengurangi angka kematian ibu atau bayi (Kementrian Kesehatan Republik Indonesia, 2016).

Kehamilan memberikan pengalaman yang berbeda pada setiap perempuan hamil. Secara umum banyak yang merasakan kebahagiaan karena menantikan kehadiran buah hati. Namun, pada saat yang bersamaan ada kalanya perempuan hamil mengalami rasa sakit fisik atau gangguan psikologis sehingga kondisi kehamilan menimbulkan kekhawatiran. Pada forum diskusi online (ibuhamil.com) ditemukan dari 38 orang yang berdiskusi mengenai hamil pada trimester pertama (1-13 minggu), 34 orang mengatakan bahwa mereka mengalami sakit atau nyeri pada perut seperti sedang menstruasi dan nyeri pada pinggang. Ada pula ibu hamil yang merasa malas, cepat lelah saat bekerja, dan ingin diperhatikan oleh suami saat merasa nyeri. Sakit fisik yang dialami ada yang berlanjut hingga di trimester kedua (Anggi, 2013). Dari 17 orang yang berdiskusi mengenai perasaan saat masa kehamilan, 12 orang mengatakan bahwa mereka sering menangis dan memiliki perasaan yang lebih sensitif, seperti mudah tersinggung (Diaanita, 2013).

Pada forum diskusi online (ibuhamil.com) yang berdiskusi mengenai kehamilan pertama, $\mathrm{S}$ mengatakan ia sangat stress saat ingin menghadapi persalinan karena baru pertama kali hamil sehingga tidak tahu bagaimana proses persalinan. A mengatakan ia merasa stress saat dulunya akan menghadapi persalinan, ia sering menonton video mengenai persalinan. Hal ini menyebabkan rasa takut yang berlebihan sehingga tekanan darahnya naik menjadi 180/130. C mengatakan ia stress memikirkan rasa sakit jika nanti harus melahirkan. D mengatakan ia sering bermimpi buruk dan ketika bangun pagi ia khawatir jika ia berada di rumah sakit. Tetapi 3 orang lainnya berpendapat berbeda, mereka menikmati masa kehamilannya dan dapat mengontrol kekhawatiran yang dirasakan (Dshe, 2014). Menurut Woods dan Lobel (dalam Lobel \& Dunkel, 2016) stress yang tinggi saat kehamilan seringkali dialami oleh perempuan yang mengalami kehamilan pertama dan perempuan yang mengalami gejala yang berbeda pada kehamilan sebelumnya.

Menurut skala social readjustment rating scale yang mengukur peristiwa hidup yang berpengaruh terhadap stress, terdapat 43 kategori yang dikelompokkan ke dalam sumber stress. Pada skala tersebut, stress yang terkait dengan kehamilan berada pada peringkat 12 sebagai peristiwa yang memengaruhi tingkat stress (Holmes \& Rahe, 1967). Pernyataan serupa juga dikemukakan oleh Susanti (2008) bahwa kehamilan biasanya diikuti oleh stress dan gelisah, baik kehamilan yang diharapkan ataupun tidak. Stress atau psychological stress merupakan suatu kondisi antara diri dan lingkungan yang memiliki kesenjangan berupa tekanan dari situasi saat sumber daya yang dimiliki individu mengganggu kesejahteraan (well-being) individu tersebut (Lazarus, 1999). Psychological stress dapat meningkatkan risiko keguguran sebesar $42 \%$ (Qu et al., 2017). Kehamilan memberikan dampak stress bagi kebanyakan wanita karena melibatkan banyak tuntutan dan perubahan dalam fisiologis dan kondisi fisik yang menandakan perubahan besar dalam peran yang melibatkan kehidupan keluarga (Lobel \& Dunkel, 2016). 
Penelitian ini bertujuan membahas stress yang terjadi pada kehamilan atau yang dikenal dengan pregnancy-specific distress (PSD). PSD merupakan kondisi distress mengenai gejala fisik pada saat kehamilan, perubahan bentuk tubuh, perubahan hubungan interpersonal dengan orang lain, proses persalinan, kesehatan bayi, cara merawat bayi yang telah lahir, dan risiko dari perawatan medis yang dilakukan (Woods-Giscombe dalam Lobel \& Dunkel, 2016). Gejala PSD ditunjukkan dengan perilaku pola diet yang buruk seperti makan makanan yang tidak sehat, melewati waktu makan, kualitas tidur yang buruk, kuantitas tidur yang kurang, tidak mau melakukan aktivitas fisik, menggunakan zat terlarang, dan melakukan aktivitas yang memiliki risiko terhadap masalah kesehatan janin (Lobel \& Dunkel, 2016).

PSD dapat memprediksi hasil dari kelahiran yaitu berat badan bayi yang rendah dan usia kehamilan yang prematur (Lobel et al., 2008; Alderdice, Lynn, Lobel, 2012; Cannella, Auerbach, Lobel, 2013; Lewis et al., 2014). Perempuan hamil yang memiliki tingkat PSD yang tinggi cenderung akan memiliki bayi dengan berat badan rendah dan kelahiran prematur. Bayi yang lahir dengan berat badan rendah akan lebih cenderung mengalami ketidakmampuan belajar, gangguan hiperaktivitas atau gangguan atensi, atau masalah pernapasan seperti asma (Santo, Portuguez, \& Nunez dalam Santrock, 2015). Penelitian menunjukkan bayi yang lahir prematur biasanya mengalami keterlambatan dalam perkembangan motorik, perilaku, dan kemampuan belajar saat usia sekolah (Moreira, Magalhaes, \& Alves, 2013).

Perempuan yang sedang hamil akan mengalami perubahan fisik dan psikologis sehingga memiliki risiko mengalami PSD. PSD yang tinggi biasanya dialami oleh perempuan yang mengalami kehamilan pertama karena kehamilan memberikan perubahan fisik dan psikologis yang belum pernah dirasakan sebelumnya. PSD akan memberikan dampak buruk untuk ibu dan janinnya. Perempuan yang sedang hamil sebaiknya mencari cara yang tepat dalam mengatasi stress yang dirasakan. Salah satu cara yang dapat dilakukan untuk mereduksi PSD adalah menggunakan art therapy atau terapi seni (Wahlbeck, Kvist, \& Landgren, 2017; Unsalver \& Sezen, 2017; Swan-Foster, 1989).

Art therapy merupakan terapi yang menggunakan materi seni untuk mengekspresikan diri dan merefleksikan perasaan. Tujuannya adalah untuk membantu menceritakan dan mengeksplorasi emosi yang sulit diungkapkan atau sebagai media untuk mengungkapkan perasaan ke dalam bentuk gambar (Edwards, 2004). Art therapy dapat mereduksi stress yang diakibatkan karena masalah fisik, emosi, dan mental, membuat seseorang lebih memahami dirinya, meningkatkan perasaan pasif menjadi aktif dan perasaan distress menjadi tenang, serta membantu mengekspresikan perasaan yang tidak disadari (Ganim, 1999; Finnegan, 2009). Art therapy yang akan digunakan pada penelitian ini adalah seni dua dimensi yaitu dengan menggambar dan melukis.

Art therapy dengan menggambar dan melukis untuk mengekspresikan emosi dapat meningkatkan prenatal attachment atau kedekatan secara emosional antara ibu dan janinnya (Chetu, 2015; Miller, 2017). Art therapy dengan menggambar dan melukis efektif untuk perempuan hamil dengan usia kehamilan trimester ketiga untuk membantu mengekspresikan perasaan takut dan khawatir pada saat akan melahirkan nantinya (Wahlbeck, Kvist, Landgren, 2017; Swan-Foster, 1989). Penelitian serupa yang dilakukan oleh Unsalver dan Sezen (2017) menunjukkan art therapy dalam bentuk visual dapat menurunkan kecemasan dan depresi pada perempuan hamil yang usia kehamilannya trimester ketiga sehingga dapat menangani rasa takut dan khawatir terhadap persalinan. 
Pada penelitian ini, kriteria partisipan adalah dewasa perempuan dewasa awal berusia 25-35 tahun yang mengalami kehamilan pertama dengan usia kehamilan trimester pertama. Partisipan dewasa awal pada umumnya mengalami proses kehamilan karena kehamilan merupakan salah satu tugas perkembangan pada usia dewasa awal (Hurlock, 1999). Menurut data Survei Sosial Ekonomi Nasional (Susenas) tahun 2015, usia 25-35 tahun termasuk usia perempuan hamil pertama kali yang paling banyak di perkotaan yaitu sebanyak 60 \% (Badan Pusat Statistik, 2015). Kriteria kehamilan pertama dipilih karena pada kehamilan pertama pada umumnya lebih cenderung menimbulkan PSD yang lebih tinggi dibandingkan jika perempuan sudah pernah hamil sebelumnya (Woods dan Lobel dalam Lobel \& Dunkel, 2016).

Kriteria usia kehamilan trimester pertama dipilih karena pada penelitian sebelumnya art therapy digunakan untuk mengatasi rasa khawatir dalam menghadapi persalinan pada ibu hamil yang usia kehamilannya trimester ketiga. Pada penelitian ini ingin membuktikan apakah art therapy dapat mengatasi PSD pada perempuan hamil dengan usia kehamilan trimester pertama. Hal ini didukung oleh fenomena yang terjadi seperti di forum diskusi online (ibuhamil.com) yang menunjukkan bahwa selain rasa takut pada proses persalinan, stress dapat dirasakan sejak trimester pertama karena ibu hamil baru merasakan perubahan fisik dan psikologis, mengalami mual, muntah, sakit pada perut dan pinggang, cepat lelah, perasaan yang menjadi lebih sensitif atau mudah tersinggung yang dapat memengaruhi hubungan mereka dengan orang lain.

\section{Rumusan Masalah}

Apakah art therapy dalam bentuk menggambar dan melukis berpegaruh untuk menurunkan PSD pada perempuan dewasa awal yang mengalami kehamilan pertama pada usia kehamilan trimester pertama?

\section{METODE PENELITIAN}

\section{Partisipan dan Prosedur Penelitian}

Karakteristik partisipan pada penelitian ini adalah (a) perempuan dewasa awal yang berusia 2535 tahun, (b) perempuan yang mengalami kehamilan pertama dengan usia kehamilan 1-13 minggu atau trimester pertama, (c) mengalami PSD yang dinilai dari skor alat ukur Revised Prenatal Distress Questionnaire (NuPDQ) yaitu 18-35, (d) memiliki indikator gejala perilaku PSD seperti makan makanan yang tidak sehat, melewati waktu makan, kualitas tidur yang buruk, kuantitas tidur yang kurang, tidak mau melakukan aktivitas fisik, menggunakan zat terlarang, merokok, minum alkohol, atau melakukan aktivitas yang memiliki risiko terhadap kesehatan janin.

Penelitian ini menggunakan desain mix method yaitu one-group pretest-posttest design dengan teknik sequential exploratory. Metode pengumpulan data yang digunakan menggunakan nonrandom sampling dengan menggunakan teknik purposive sampling. Peneliti akan mencari partisipan dengan mengunjungi Puskesmas X dan menyebarkan informasi melalui media sosial untuk mendapatkan partisipan yang sesuai dengan kriteria yang sudah ditetapkan.

\section{Pengukuran/ Instrument Penelitian}

Alat ukur NuPDQ dikembangkan oleh Lobel (2008). Alat ukur NuPDQ merupakan alat ukur unidemensional yang mengukur PSD. NuPDQ berisi pernyataan mengenai perasaan (terganggu, sedih, khawatir) terkait aspek kehamilan seperti perawatan medis, pengasuhan bayi, perubahan bentuk tubuh, hubungan dengan orang lain, persalinan, dan kesehatan bayi. 
Alat ukur NuPDQ merupakan prediktor yang signifikan terhadap usia kehamilan dan berat badan bayi saat lahir. Semakin tinggi PSD, maka usia kehamilan akan lebih singkat atau prematur dan berat badan bayi yang rendah (Cannella, Auerbach, \& Lobel, 2013; Alderdice, Lynn, \& Lobel, 2012). Koefisien reabilitas cronbach alpha pada alat ukur NuPDQ adalah 0.80-0.87 (Lewis et al., 2014; Yali \& Lobel; Alderlice et al. dalam Zwicht, Crone, Lith, \& Rijnders, 2016). Menurut Nunnaly (dalam Pallant, 2005) nilai koefisien cronbach alpha yang baik minimal adalah 0.7. Hal ini menunjukkan alat ukur NuPDQ reliabel atau konsisten dalam mengukur PSD.

Pada hasil adaptasi NuPDQ ke dalam bahasa Indonesia, berdasarkan uji internal consistency, semua item alat ukur NuPDQ dinyatakan lolos karena nilai korelasi berada di atas critical value pearson (> 0.195). Berdasarkan hasil uji reliabilitas menunjukkan koefisien reliabilitas cronbach alpha untuk alat ukur NuPDQ adalah 0.9. Hal ini menunjukkan alat ukur NuPDQ memiliki validitas dan reliabilitas yang sangat baik (Caestara, 2016).

Alat ukur NuPDQ merupakan alat ukur berupa self-report, yaitu individu mengisi sendiri jawaban yang sesuai dengan keadaan dirinya saat itu. Seluruh item direspon dalam 3 pilihan skala, yaitu ( $0=$ tidak sama sekali, $1=$ agak sering, $2=$ sangat sering). Terdapat 17 pernyataan mengenai kehamilan dan terdapat 1 pertanyaan terbuka yang menanyakan apakah ada hal lain yang membuat wanita hamil merasa terganggu akan kehamilannya. Semua pernyataan pada alat ukur NuPDQ merupakan butir positif. Contoh item pada alat ukur NuPDQ adalah "Saya merasa terganggu, sedih, atau khawatir jika nantinya akan merawat bayi yang baru lahir", "Saya merasa terganggu, sedih, atau khawatir pada apa yang akan terjadi selama proses persalinan nantinya"

Skor PSD diperoleh dengan cara menjumlahkan skor dari setiap item pernyataan pada alat ukur NuPDQ. Semakin tinggi skor NuPDQ, maka semakin tinggi PSD yang dirasakan. Peneliti memilih partisipan dengan yang memiliki skor NuPDQ yaitu 18-35 berdasarkan penggunaan statistik hipotetik atau mean hipotetik yaitu dengan melihat nilai tengah dari alat ukur yang digunakan. Selain itu, akan dilakukan expert judgment terhadap alat ukur yang sudah diisi oleh partisipan. Berikut merupakan rancangan art therapy untuk mengatasi PSD.

Tabel 1. Rancangan intervensi art therapy

\begin{tabular}{|c|c|c|c|}
\hline Sesi & Kegiatan & Tujuan & Media \\
\hline \multirow[t]{2}{*}{ Sesi I } & $\begin{array}{l}\text { Pengisian kuesioner pretest } \\
\text { NuPDQ }\end{array}$ & Mengetahui gambaran PSD partisipan. & $\begin{array}{l}\text { - Kuesioner } \\
\text { NuPDQ }\end{array}$ \\
\hline & $\begin{array}{ll}\text { Membangun } & \text { rapport } \\
\text { dengan partisipan } & \end{array}$ & $\begin{array}{l}\text { Terciptanya rasa percaya pada partisipan } \\
\text { terhadap terapis. }\end{array}$ & - Alat tulis \\
\hline \multirow[t]{3}{*}{$\begin{array}{l}\text { Sesi II: } \\
\text { Expressing } \\
\text { emotion }\end{array}$} & $\begin{array}{l}\text { Tugas I: Expressing your } \\
\text { emotion verbally }\end{array}$ & $\begin{array}{l}\text { Partisipan dapat mengekspresikan emosi } \\
\text { secara verbal sehingga partisipan mengetahui } \\
\text { perbedaan mengekspresikan emosi secara } \\
\text { verbal dan gambar. }\end{array}$ & $\begin{array}{l}\text { - Kertas } \\
\text { gambar A3 } \\
\text { - Pensil } \\
\text { - Cat poster }\end{array}$ \\
\hline & $\begin{array}{l}\text { Tugas II: Expressing your } \\
\text { emotion with imagery }\end{array}$ & $\begin{array}{l}\text { Mengarahkan partisipan untuk berimajinasi } \\
\text { sehingga dapat mengekspresikan emosi } \\
\text { dengan menggambar. }\end{array}$ & $\begin{array}{l}\text { - Kuas } \\
\text { - Palet } \\
\text { - Krayon }\end{array}$ \\
\hline & $\begin{array}{l}\text { Tugas III: Creating an } \\
\text { artwork of intention }\end{array}$ & $\begin{array}{l}\text { Membantu partisipan menemukan hal positif } \\
\text { dalam penyembuhan diri. }\end{array}$ & - Spidol \\
\hline \multirow[t]{3}{*}{$\begin{array}{l}\text { Sesi III: } \\
\text { Healing the mind }\end{array}$} & $\begin{array}{l}\text { Tugas I: Assessing and } \\
\text { releasing your stress- } \\
\text { producing emotions }\end{array}$ & $\begin{array}{l}\text { Membantu partisipan menyalurkan stress } \\
\text { yang dimiliki ke dalam bentuk gambar. }\end{array}$ & $\begin{array}{l}\text { - Kertas } \\
\text { gambar A3 } \\
\text { - Pensil }\end{array}$ \\
\hline & $\begin{array}{l}\text { Tugas II: Transformation } \\
\text { through reenvisioning }\end{array}$ & $\begin{array}{l}\text { Membantu partisipan untuk mengubah } \\
\text { penilaian pengalaman negatif menjadi positif. }\end{array}$ & $\begin{array}{l}\text { - Cat poster } \\
\text { - Kuas }\end{array}$ \\
\hline & Tugas III: Replacing the & Menciptakan simbol atau gambar yang & - Palet \\
\hline
\end{tabular}




\begin{tabular}{|c|c|c|c|}
\hline & $\begin{array}{l}\text { painful image with your } \\
\text { new positive image }\end{array}$ & $\begin{array}{l}\text { menggantikan gambar yang tidak nyaman dan } \\
\text { menyakitkan. }\end{array}$ & \\
\hline $\begin{array}{l}\text { Sesi IV: } \\
\text { Healing the body }\end{array}$ & $\begin{array}{l}\text { Tugas I: Discovering the } \\
\text { metaphor behind your } \\
\text { physical symptoms } \\
\text { Tugas II: Creating a } \\
\text { symbol that represent how } \\
\text { to express your needs } \\
\text { Tugas III: Seeing yourself } \\
\text { as healthy and well }\end{array}$ & $\begin{array}{l}\text { Membantu partisipan memahami gejala fisik } \\
\text { yang dialami. } \\
\text { Menentukan simbol mengekspresikan } \\
\text { kebutuhan partisipan. } \\
\text { Membantu partisipan menemukan gambar } \\
\text { atau simbol dirinya yang positif. }\end{array}$ & $\begin{array}{l}\text { - Kertas } \\
\text { gambar A3 } \\
\text { - Pensil } \\
\text { - Cat poster } \\
\text { - Kuas } \\
\text { - Palet }\end{array}$ \\
\hline $\begin{array}{l}\text { Sesi V: } \\
\text { Transformation of } \\
\text { the spirit }\end{array}$ & $\begin{array}{l}\text { Tugas I: The rebirth of } \\
\text { your devine self } \\
\text { Tugas II: Discovering your } \\
\text { soul's purpose }\end{array}$ & $\begin{array}{l}\text { Membantu partisipan menerima pengalaman } \\
\text { masa lalu yang negatif dan mengubah diri } \\
\text { menjadi positif. } \\
\text { Membantu partisipan mengetahui atau } \\
\text { menyadari tujuan hidupnya. }\end{array}$ & $\begin{array}{l}\text { - Kertas } \\
\text { gambar A3 } \\
\text { - Pensil } \\
\text { - Cat poster } \\
\text { - Kuas } \\
\text { - Palet }\end{array}$ \\
\hline Sesi VI: & $\begin{array}{l}\text { Review sesi sebelumnya } \\
\text { Pengisian kuesioner } \\
\text { posttest NuPDQ } \\
\text { Terminasi }\end{array}$ & $\begin{array}{l}\text { Partisipan memahami setiap sesi yang sudah } \\
\text { dilakukan. } \\
\text { Terapis mengetahui gambaran PSD partisipan } \\
\text { setelah proses terapi. } \\
\text { Terapis menjelaskan bahwa proses terapi telah } \\
\text { selesai. }\end{array}$ & $\begin{array}{l}\text { - Kuesioner } \\
\text { NuPDQ } \\
\text { - Alat tulis }\end{array}$ \\
\hline
\end{tabular}

Sumber (Ganim, 1998)

\section{HASIL DAN PEMBAHASAN}

Berikut adalah identitas partisipan pada penelitian ini.

Tabel 2. Identitas partisipan

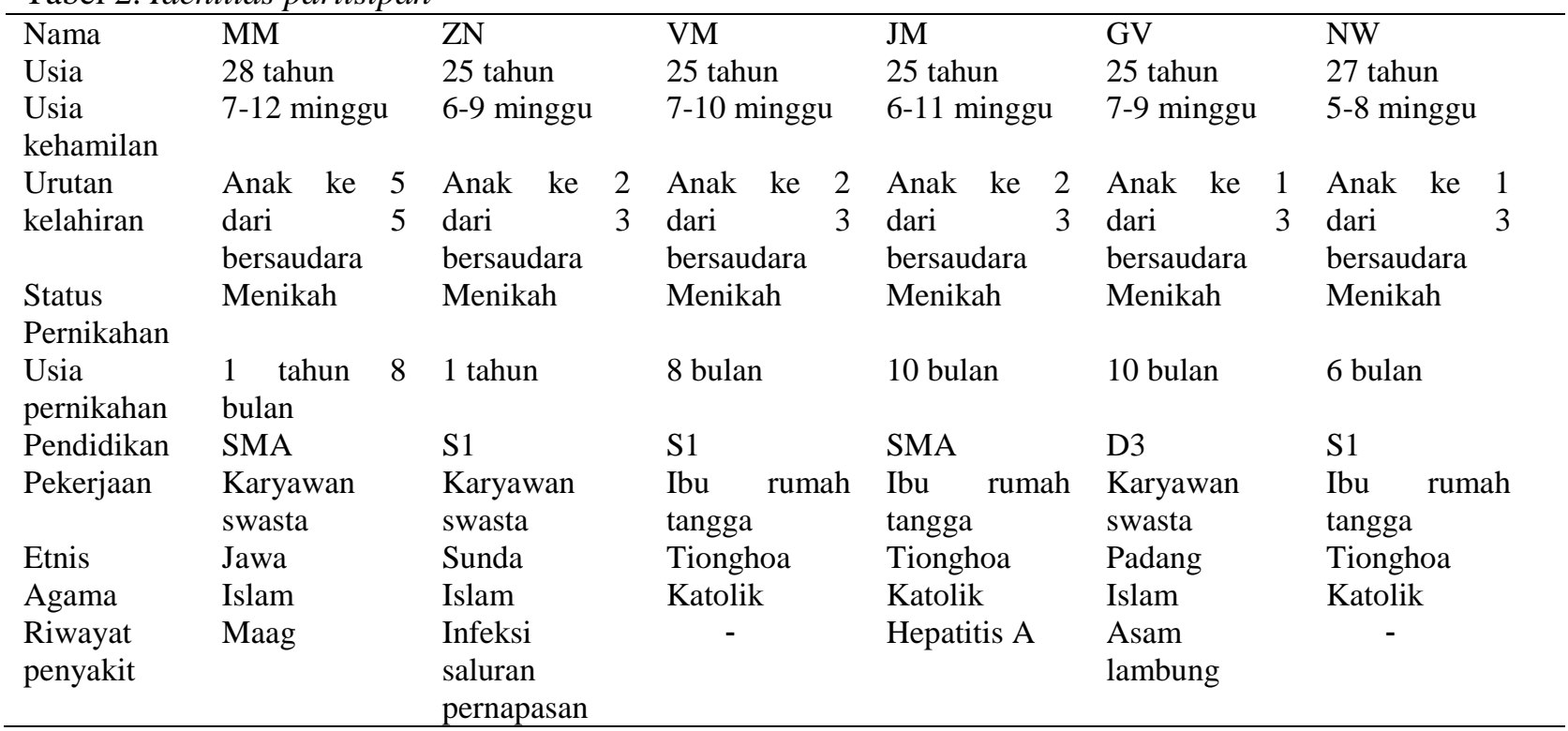

Tabel 3. Hasil analisis antar partisipan

\begin{tabular}{lll}
\hline Sesi & Kegiatan & \multicolumn{1}{c}{ Analisis } \\
\hline 1 & $\begin{array}{l}\text { Wawancara } \\
\text { dan pretest }\end{array}$ & $\begin{array}{l}\text { Seluruh partisipan menyadari PSD yang dialami yaitu karena masalah kesehatan } \\
\text { seperti flek dan pendarahan, kelelahan bekerja, mendengarkan cerita orang lain, } \\
\text { pengalaman traumatis pernah dibully, dan mengonsumsi obat yang tidak aman untuk } \\
\text { ibu hamil. }\end{array}$ \\
& Expressing & Tujuan pada sesi ini tercapai yaitu partisipan dapat mengekspresikan emosi negatif \\
\hline
\end{tabular}




\begin{tabular}{|c|c|c|}
\hline & $\begin{array}{l}\text { your } \\
\text { emotion }\end{array}$ & $\begin{array}{l}\text { yang mereka rasakan. Semua partisipan berusaha untuk mengekspresikan emosi } \\
\text { mereka dengan gambar sesuai dengan instruksi yang diberikan. }\end{array}$ \\
\hline 3 & $\begin{array}{l}\text { Healing the } \\
\text { mind }\end{array}$ & $\begin{array}{l}\text { Tujuan pada sesi ini tercapai karena seluruh partisipan dapat menggambarkan hal yang } \\
\text { dapat menyembuhkan pikiran negatif. Tiga partisipan menggambar air sungai, pantai, } \\
\text { dan laut yang dapat menenangkan pikiran negatif mereka. Dua partisipan } \\
\text { menggambarkan anggota keluarga yang dapat menenangkan perasaan negatif yang } \\
\text { dirasakan. Satu partisipan mengungkapkan dapat membuat pikirannya menjadi lebih } \\
\text { nyaman dengan makan cokelat. }\end{array}$ \\
\hline 4 & $\begin{array}{l}\text { Healing the } \\
\text { body }\end{array}$ & $\begin{array}{l}\text { Tujuan pada sesi ini tercapai karena seluruh partisipan dapat menggambarkan sakit } \\
\text { fisik dan memahami hal yang dapat menyembuhkan. Dua partisipan menggambarkan } \\
\text { simbol hati yang menandakan cinta dari orang sekitar yang dapat menyembuhkan sakit } \\
\text { fisik. Dua partisipan menggambar makanan yang dapat menyembuhkan. Satu } \\
\text { partisipan menggambarkan air, dan satu partisipan menggambarkan tempat tidur. }\end{array}$ \\
\hline 5 & $\begin{array}{l}\text { Transforma } \\
\text { tion of the } \\
\text { spirit }\end{array}$ & $\begin{array}{l}\text { Tujuan pada sesi ini tercapai karena seluruh partisipan menunjukkan perubahan diri } \\
\text { dan tujuan hidup yang positif. Empat partisipan menggambarkan perubahan dirinya } \\
\text { sebagai tanaman seperti bunga dan pohon, satu partisipan dengan matahari, dan satu } \\
\text { partisipan dengan kura-kura. Seluruh partisipan mengetahui tujuan hidupnya yaitu } \\
\text { dekat dengan Tuhan, cinta dan kepedulian, serta keluarga. }\end{array}$ \\
\hline 6 & $\begin{array}{l}\text { Posttest dan } \\
\text { terminasi }\end{array}$ & $\begin{array}{l}\text { Tujuan pada seluruh sesi tercapai karena seluruh partisipan mengalami penurunan PSD } \\
\text { dan menyadari manfaat pada intervensi yang diberikan. Meskipun ada partisipan yang } \\
\text { kurang menyukai kegiatan menggambar, mereka tetap mau melakukannya dan } \\
\text { merasakan manfaat dengan menggambar karena dapat mengekspresikan pikiran dan } \\
\text { perasaan mereka. }\end{array}$ \\
\hline
\end{tabular}

Tabel 4. Perbandingan hasil pretest dan posttest kuesioner NuPDQ

\begin{tabular}{ccccccc}
\hline \multirow{2}{*}{ NuPDQ } & \multicolumn{7}{c}{ Partisipan } \\
\cline { 2 - 7 } & MM & ZN & VM & JM & GV & NW \\
\hline Pretest & 23 & 20 & 22 & 18 & 19 & 19 \\
Posttest & 12 & 4 & 9 & 7 & 10 & 13 \\
Perubahan & 11 & 16 & 13 & 11 & 9 & 6 \\
\hline
\end{tabular}

Seluruh partisipan mengalami PSD pada kehamilannya. Seluruh partisipan menunjukkan penurunan PSD dalam cara merawat bayi, kesehatan bayi, perawatan medis, perubahan hubungan dengan orang lain, dan persalianan. Partisipan MM masih mengalami kekhawatiran terkait gejala fisik yaitu perut yang kencang dan sakit pinggang. Perut kencang pada kehamilan awal dapat disebabkan karena pertumbuhan rahim yang mendorong otot perut sehingga terasa kencang. Selain itu, adanya gas berlebih dalam perut atau perut kembung juga bisa menjadi penyebab perut kencang (Susanti, 2008). Kekhawatiran MM juga terjadi karena ia mengalami pendarahan dua minggu sebelumnya. Empat orang partisipan mengalami kekhawatiran terkait perubahan berat badan dan bentuk tubuh karena kehamilan. Kekhawatiran keempat partisipan tersebut menurun setelah diberikan intervensi art therapy.

Art therapy dapat digunakan untuk mengekspresikan emosi negatif yang menyebabkan PSD pada partisipan sehingga dapat mereduksi stress karena masalah fisik, dan emosi. Emosi tersebut dapat diakses dengan panduan visualisasi (guided visualization) yang diberikan peneliti kepada partisipan sebelum proses menggambar dan melukis dimulai. (Ganim, 1998). Peneliti memberikan relaksasi dan instruksi kepada partisipan terkait pikiran dan perasaan partisipan yang nantinya akan diekspresikan. Emosi tersebut dapat dilepaskan dengan mengekspresikan secara imajinasi dengan menggambar dan melukis. Seluruh partisipan mempraktekkan teknik relaksasi sebelum menggambar sehingga mereka dapat mengungkapkan perasaan, konflik, dan harapannya untuk mengubah diri menjadi lebih nyaman dan positif. 
Seluruh partisipan menunjukkan perubahan diri menjadi positif setelah proses intervensi. Partisipan MM yang kesulitan mengomunikasikan perasaan kepada suami dapat menyampaikan perasaanya sehingga suaminya mengerti apa yang ia pikirkan dan rasakan. Partisipan $\mathrm{ZN}$ menjadi lebih sadar akan reaksi tubuhnya ketika perlu beristirahat dan tidak mengalami kesulitan tidur seperti sebelumnya. Partisipan VM memiliki pola makan yang sudah teratur. Partisipan JM mengetahui cara untuk mengatasi kekhawatirannya yaitu dengan berdoa dan mencari dukungan dari orang lain. Partisipan GV menjadi lebih fokus memikirkan kehamilannya dan tidak memikirkan perkataan orang lain. Partisipan NW dapat berdoa ketika ia merasa khawatir dan tidak mencari informasi yang dapat membuat dirinya khawatir.

Seluruh partisipan dapat mengungkapkan PSD yang dirasakan melalui gambar. Partisipan ZN paling tinggi penurunan PSD yaitu 16 poin. ZN memiliki pengetahuan dan insight yang baik terkait kekhawatirannya. Partisipan $\mathrm{ZN}$ dan VM merasa nyaman saat mempraktekkan teknik relaksasi dan melakukan teknik relaksasi tersebut di rumah untuk mengatasi kekhawatirannya. Menurut hasil penelitian Sutrisno (2017), relaksasi pada ibu hamil dapat menurunkan kecemasan dan kekhawatiran. Partisipan MM dan JM mengalami penurunan PSD karena sesi intervensi dan mendapat dukungan sosial dari lingkungannya. Partisipan MM mendapat dukungan dari orangtuanya sejak ia pindah ke rumah orangtuanya. Partisipan JM mendapat dukungan sosial karena saat ia khawatir, ia menceritakan kekhawatirannya pada temannya. Dukungan sosial yang tinggi dari lingkungan akan menurunkan PSD pada ibu hamil (Dacosta dalam Guardino \& Schettler, 2014). Partisipan NW paling rendah penurunan PSD yaitu 6 poin karena ia merasa memerlukan proses yang panjang untuk berubah menjadi dirinya yang lebih positif.

Salah satu hal yang mendukung keberhasilan intervensi yang diberikan adalah kesungguhan para partisipan untuk mengikuti intervensi (Magrabi, Li, Dunn, \& Coerira, 2011). Setiap partisipan bersedia mengikuti instruksi yang diberikan peneliti dan mau terbuka pada peneliti dalam menceritakan pikiran dan perasaan mereka. Meskipun terkadang kondisi fisik partisipan tidak sehat seperti merasa mual, sakit pada pinggang atau punggung, partisipan tetap mau melaksanakan sesi intervensi hingga selesai. Partisipan yang kurang menyukai kegiatan menggambar tetap mau mencoba untuk mendengarkan instruksi dan mengekspresikan perasaannya.

Hasil penelitian menunjukkan art therapy dalam bentuk menggambar dan melukis dapat membantu partisipan mengekspresikan emosi negatifnya, mengungkapkan harapan, membantu partisipan mengubah diri menjadi lebih positif, dan menyadari tujuan hidup sehingga dapat membantu menurunkan PSD. Berdasarkan hasil uji statistik non-parametrik the Wilcoxon Ranked test menunjukkan bahwa art therapy dalam bentuk menggambar dan melukis secara signifikan dapat menurunkan skor PSD keenam partisipan dalam penelitian ini $(Z=-2.207$, $\mathrm{p}=0.027)$.

\section{KESIMPULAN DAN SARAN}

Berdasarkan hasil intervensi art therapy pada penelitian ini, disimpulkan bahwa art therapy dengan media menggambar dan melukis berpengaruh untuk menurunkan pregnancy-specific distress (PSD) pada perempuan dewasa awal yang mengalami kehamilan pertama dan memiliki usia kehamilan trimester pertama. Seluruh partisipan mengalami penurunan terhadap PSD terkait cara merawat bayi, kesehatan bayi, perawatan medis, perubahan hubungan interpersonal dengan orang lain, persalinan, dan perubahan bentuk tubuh. Tetapi, satu dari enam partisipan masih merasakan PSD terkait gejala fisik yang tidak berkurang karena mengalami kondisi medis yaitu 
pendarahan. Perhitungan statistik non-parametrik Wilcoxon Ranked test terhadap hasil pretest dan posttest Revised Prenatal Distress Questionnaire (NuPDQ) menunjukkan adanya penurunan PSD yang signifikan dari keenam partisipan. Hal ini menandakan perasaan khawatir, sedih, dan terganggu terkait kehamilan pada keenam partisipan sudah berkurang.

Seluruh partisipan menunjukkan perubahan diri menjadi positif setelah proses intervensi. Partisipan MM yang kesulitan mengomunikasikan perasaan kepada suami dapat menyampaikan perasaanya sehingga suaminya mengerti apa yang ia pikirkan dan rasakan. Partisipan ZN menjadi lebih sadar akan reaksi tubuhnya ketika perlu beristirahat dan tidak mengalami kesulitan tidur seperti sebelumnya. Partisipan VM memiliki pola makan yang sudah teratur. Partisipan JM mengetahui cara untuk mengatasi kekhawatirannya yaitu dengan berdoa dan mencari dukungan dari orang lain. Partisipan GV menjadi lebih fokus memikirkan kehamilannya dan tidak memikirkan perkataan orang lain. Partisipan NW dapat berdoa ketika ia merasa khawatir dan tidak mencari informasi yang dapat membuat dirinya khawatir.

Saran untuk penelitian selanjutnya dapat menambah jumlah sampel penelitian dan meneliti karakteristik sampel yang berbeda seperti usia partisipan dengan rentang yang berbeda dan usia kehamilan pada trimester kedua atau ketiga untuk membuktikan efektivitas art therapy. Penelitian selanjutnya juga dapat menggunakan metode art therapy selain media menggambar dan melukis. Kegiatan art therapy lainnya yang dapat dilakukan misalnya menjahit atau merajut untuk mempersiapkan kelahiran bayi.

\section{Ucapan Terima Kasih}

Terima kasih kepada puskesmas $\mathrm{X}$ yang sudah berpartisipasi dan seluruh partisipan yang bersedia mengikuti proses penelitian hingga selesai.

\section{REFERENSI}

Alderdice, F., Lynn, F., \& Lobel, M. (2012). A review and psychometric evaluation of pregnancy-specific stress measures. Journal of Psychosomatic Obstetrics \& Gynecology, 33(2), 62-77. doi:10.3109/0167482x.2012.673040

Anggi. (2013, 14 Januari). Kram dan nyeri di waktu hamil muda, wajarkah? [Diskusi forum online]. Diakses pada 19 Juni 2018 dari http://ibuhamil.com/diskusi-umum/20532-kramnyeri-di-waktu-hamil-muda-wajarkah.html

Badan Pusat Statistik. (2015). Profil kesehatan ibu dan anak 2015.

Caestara, A. N. (2016). Gambaran pregnancy-specific distress dan strategi coping pada perempuan remaja yang hamil di kalimantan barat (Skripsi). Archives of the Fakultas Psikologi Universitas Katolik Indonesia Atma Jaya, Jakarta.

Cannella, D., Auerbach, M., \& Lobel, M. (2013). Predicting birth outcomes: Together, mother and health care provider know best. Journal of Psychosomatic Research, 75(4), 299-304. doi:10.1016/j.jpsychores.2013.08.004

Chetu, C. V. (2015). The effect of art therapy techniques of prenatal maternal fetal attachment. Journal of Experiential Psychotherapy, 18(70), 14-19.

Crocker, L., \& Algina, J. (2008). Introduction to classical \& modern test theory. Ohio, Mason: Cengange Learning.

Diaanita. (2013, 7 Maret). Sering menangis [Diskusi forum online]. Diakses pada 19 Juni 2018 dari http://ibuhamil.com/ngobrol-apa-saja/25348-sering-menangis.html 
Dshe, D. (2014). Stres jelang lahiran anak pertama [Diskusi forum online]. Diakses pada 23 Juni 2018 dari http://ibuhamil.com/diskusi-umum/53770-stres-jelang-lahiran-anakpertama.html

Finnegan, J. M. (2009). The effect of art therapy on depression (Thesis). Adlerian Counseling and Psychotherapy and Art therapy. Diakses pada 16 Juni 2018 dari http://alfredadler.edu/sites/default/files/Finnegan\%20MP\%202009.pdf

Ganim, B. (1998). Art and healing: Using expressive art to heal your body, mind, and spirit. New York, NY: Publication Data.

Ganim, B. (1999). Visual joumaling. Wheaton, IL: Quest Books.

Guardino, C. M. \& Schetter, C. D. (2014). Understanding pregnancy anxiety. Zero to Three, 1221.

Holmes, T. \& Rahe, R. (1967). Holmes-Rahe social readjustment rating scale. Journal of Psychosomatic Research, 11(2), 213-218.

Hurlock, E. B. (1999). Psikologi perkembangan. Jakarta: Erlangga.

Kementrian Kesehatan Republik Indonesia. (2016). Profil kesehatan Indonesia tahun 2016. $\begin{array}{lllll}\text { Diakses } & \text { pada } & 19 & \text { Juni } & 2016\end{array}$ http://www.depkes.go.id/resources/download/pusdatin/profil-kesehatan-indonesia/ProfilKesehatan-Indonesia-2016.pdf

Lazarus, R. S. (1999). Stress and emotion. New York: Springer Publishing Company Inc.

Lestari, S. (2012). Psikologi keluarga: Penanaman nilai dan penanganan konflik dalam keluarga. Jakarta: Kencana Prenada Media Group.

Lewis, H. J., Kershaw, T. S., Earnshaw, V. A., Yonkers, K. A., Lin, H., \& Ickovics, J. R. (2014). Pregnancy-specific stress, preterm birth, and gestational age among high-risk young women. Health Psychology, 33(9), 1033-1045. doi:10.1037/a0034586

Lobel, M., Cannella, D. L., Devincent, C. D., Schneider, J., Graham, J. E., \& Meyer, B. A. (2008). Pregnancy-specific stress, prenatal health behaviors and birth outcomes. Health psychology, 27(5), 604-615. doi: 10.1037/a0013242

Lobel, M., \& Dunkel, S. C. (2016). Pregnancy and prenatal stress: In Howard S. Friedman (Editor in Chief). Encyclopedia of mental health ( $2^{\text {nd }}$ edition), 3, 318-329.

Magrabi, F., Li, S. Y., Dunn, A. G., \& Coeira, E. (2011). Challenges in measuring the impact of interruption on patient safety and workflow outcomes. Methods of Information in Medicine, 50(5), 447-453.

Miller, A. (2017). Building a secure attachment during pregnancy (Tesis). Adlerian Counseling and Psychotherapy.

Moreira, R. S., Magalhaes, L. C., \& Alves, C. R. L. (2013). Effect of preterm birth on motor development, behavior, and school performance of school-age children: a systematic review. Journal de Pediatria, 90(2), 119-134.

Pallant, J. (2005). SPSS survival manual: A step by step guide to data analysis using SPSS for windows version 12 (2nd ed.). Sydney: Allen \& Unwin.

Qu, F., Yan, W., Yu, H. Z., Barry, J., Ding T., Biao, G., Muscat, R., Todd, B. K., Wang, F. F., \& Hardima, P. J. (2017). The association between psychological stress and miscarriage: A systematic review and metanalysis. Scientific Reports.

Santrock, J. W. (2015). Life span development. (14th ed). New York, NY: McGraw-Hill.

Susanti, N. N. (2008). Psikologi kehamilan. Jakarta: EGC. Diakses pada 19 Juni 2018 dari https://books.google.co.id/books?id=AYbr7czGm9EC\&pg=PR7\&hl=id\&source=gbs_selec ted_pages\&cad $=3 \# \mathrm{v}=$ onepage $\& \mathrm{q} \& \mathrm{f}=$ false

Sutrisno. (2017). Efektivitas teknik relaksasi terhadap penurunan tingkat kecemasan ibu inpartu kala I. jurnal Kesehatan,5(2), 35-41. 
Swan-Foster, N. (1989). Images of pregnant women: Art therapy is a tool for transformation. The Arts in Psychotherapy, 16, 283-292.

Unsalver, B. O., \& Sezen, C. (2017). Group art therapy for the management of fear of giving birth. European Psychiatry, 41. doi:10.1016/j.eurpsy.2017.01.1868

Wahlbeck, H., Kvist, L. J., \& Landgren, K. (2017). Gaining hope and self-confidence: An interview study of women's experience of treatment by art therapy for severe fear of childbirth. Women and Birth, 728, 1-8. doi.org/10.1016/j.wombi.2017.10.008

Zwicht, B. S., Crone, M. R., Lith, J. M., \& Rijnders, M. E. (2016). Group based prenatal care in a low-and high risk population in the Netherlands: A study protocol for a stepped wedge cluster randomized controlled trial. BMC Pregnancy and Childbirth, 16(1), 1-10. doi:10.1186/s12884-016-1152-0 